\title{
Cięcia przygodne i pielęgnacyjne a ilość martwego drewna na terenie obszaru Natura 2000 „Puszcza Niepołomicka”
}

\author{
Marcin Adam Piszczek, Katarzyna Izworska, Pawee Kapusta, \\ PrzemysŁaw Kurek, Łukasz Piechnik, Barbara Seget, \\ GraŻyna SZareK-Łukaszewska, Tomasz Zielonka i Jan Holeksa
}

\begin{abstract}
Piszczek, M. A., Izworska, K., Kapusta, P., Kurek, P., Piechnik, Ł., Seget, B., Szarek-ŁukaSZEWSKA, G., ZielonKA, T. AND HoleKsA, J. 2020. Amount of deadwood left after incidental felling and thinning in the Niepolomice Forest Natura 2000 area. Fragmenta Floristica et Geobotanica Polonica 27(1): 155-167. Kraków. e-ISSN 2449-8890, ISSN 1640-629X.
\end{abstract}

\begin{abstract}
A study of 183 sample plots in the Niepołomice Forest District was conducted to determine the impact of timber extraction during incidental felling and thinning on the type and amount of deadwood left to decay naturally in the forest. Deadwood was measured and classified as logs or snags, and three types of forests stand were distinguished: coniferous, oak-hornbeam, and black alder swamp forest. The amount of timber harvested in 2010-2015 in 365 selected forest compartments was grouped according to 14 types of silviculture practice. A large amount of timber was extracted during incidental felling as well as thinning, when dead and dying trees were cut and partially extracted from the forest. Harvesting intensity was positively correlated with the amount of logs only in the less accessible black alder forests. In oak-hornbeam forest, the more timber extracted, the lower the amount of deadwood present. To increase the volume of deadwood and lower the economic loss, timber extraction during incidental felling and thinning should be limited.

KEY WORDS: deadwood, forest management, incidental felling, thinning, timber harvesting, Natura 2000

M. A. Piszczek (autor korespondencyjny), Wydziat Leśny, Katedra Zarzqdzania Zasobami Leśnymi, Uniwersytet Rolniczy im. Hugona Kotłataja w Krakowie, Al. 29 Listopada 4, 31-425 Kraków, Polska; rlpiszcz@cyf-kr.edu.pl

G. Szarek-Lukaszewska, P. Kapusta, L. Piechnik, B. Seget, Instytut Botaniki im. W. Szafera Polskiej Akademii Nauk, ul. Lubicz 46, 31-512 Kraków, Polska

P. Kurek, J. Holeksa, Zakład Ekologii Roślin i Ochrony Środowiska, Wydziat Biologii, Uniwersytet im. Adama Mickiewicza w Poznaniu, ul. Uniwersytetu Poznańskiego 6, 61-614 Poznań; Polska

K. Izworska, T. Zielonka, Instytut Biologii, Katedra Botaniki, Uniwersytet Pedagogiczny im. Komisji Edukacji Narodowej w Krakowie, ul. Podchorażych 2, 30-084 Kraków, Polska
\end{abstract}

\section{WSTĘP}

Ustawa o lasach (UsTAWA 1991) wdrożyła do praktyki gospodarczej pojęcie trwale zrównoważonej gospodarki leśnej, mającej na celu ochronę lasów i ich korzystnego wpływu na środowisko i różnorodność biologiczną przy jednoczesnym pozyskaniu drewna i surowców niedrzewnych. Prace hodowlane i sposób użytkowania lasu wywierają istotny wpływ 
na obecność w lesie gospodarczym drzew obumierających, obumarłych, złomów i wywrotów. W przeszłości Zasady hodowli lasu (ZASADY 2012) nakazywały usuwanie drzew o gorszej jakości, uszkodzonych przez czynniki biotyczne lub abiotyczne oraz zamierających z innych przyczyn. Celem tych działań było przede wszystkim ograniczenie występowania szkodliwych z punktu widzenia gospodarczego owadów oraz grzybów. Cięcia pielęgnacyjne - czyszczenia i trzebieże - mają także na celu zwiększanie przyrostu i poprawę jakości technicznej oraz użytkowej drewna, co w efekcie końcowym winno zwiększać jego wartość rynkową.

W Lasach Państwowych od kilkunastu lat wprowadzany jest w życie program zwiększania ilości starych, zamierających, dziuplastych i obumarłych drzew oraz pozostawiania na pniu części drzew do ich biologicznej śmierci (REFEROWSKA-CHODAK 2014). Wyznaczenie obszarów Natura 2000 i związane z tym zmiany, choć nie zabraniają użytkowania lasu, to wpływają dodatkowo na ograniczenie pozyskania drewna (KAPUŚCIŃSKI 2007). Według przyjętych zaleceń jednym z warunków właściwej ochrony większości siedlisk leśnych w Polsce jest obecność martwego drewna w ilości co najmniej $20 \mathrm{~m}^{3} /$ ha (Mróz 2012). Taka ilość martwego drewna, jako minimalny stan, została również zarekomendowana dla grądów w planie zadań ochronnych dla Obszaru Specjalnej Ochrony Ptaków Natura 2000 „Puszcza Niepołomicka” PLB120002 (ZARZĄDZENIE 2014).

Można się spodziewać, że wykonywanie zabiegów gospodarki leśnej w Puszczy Niepołomickiej już od kilkunastu lat uwzględnia jej szczególny status ochronny, a w szczególności konieczność zwiększenia ilości martwych drzew. Uzasadnione wydaje się zatem przypuszczenie, że ilość martwego drewna, która znajduje się obecnie w Puszczy Niepołomickiej, jest pozytywnie związana z natężeniem zabiegów gospodarczych, zarówno cięć przedrębnych jak i rębnych, a także nieplanowanych cięć przygodnych, ukierunkowanych na bieżące usuwanie z lasu obumarłych drzew oraz wywrotów i złomów. Należałoby oczekiwać, że jeżeli w trakcie wykonywania cięć uwzględniona jest potrzeba pozostawiania w lesie gospodarczym części martwych i zamierających pni, ilość martwego drewna będzie wzrastała w miarę zwiększania intensywności tych zabiegów. Celem naszych badań jest zweryfikowanie powyższej hipotezy o pozytywnym związku intensywności cięć przygodnych i ilości martwego drewna pozostawionego w lesie gospodarczym, jednocześnie będącym obszarem Natura 2000. Podobnego związku można oczekiwać w przypadku planowanych cięć przedrębnych.

\section{CHARAKTERYSTYKA OBIEKTU BADAŃ}

Badania przeprowadzono w kompleksie leśnym Puszczy Niepołomickiej, znajdującym się pod zarządem Nadleśnictwa Niepołomice, Regionalnej Dyrekcji Lasów Państwowych w Krakowie (województwo małopolskie). Według regionalizacji przyrodniczo-leśnej znajduje się on w VI Krainie Małopolskiej (ZIELONY \& KLICZKOwSKA 2012). Przeważająca część (8000 ha) jest zlokalizowana w 11 dzielnicy Wysoczyzny Sandomierskiej, natomiast mniejsza, północna część (2000 ha) znajduje się w 10 dzielnicy Niziny Sandomierskiej. Według danych zawartych w Planie Urządzenia Lasu, powierzchnia zarządzana przez Nadleśnictwo 
Niepołomice wynosi 10 924,60 ha, z czego powierzchnia leśna zajmuje 10 181,66 ha i jest podzielona na 409 oddziałów (PUL 2011).

Puszcza Niepołomicka składa się z czterech kompleksów: Głównego (8500,50 ha), Grobla (1526,36 ha), Grobelczyk (256,71 ha) oraz Koło (217,21 ha). Zapas drewna w lasach zarządzanych przez Nadleśnictwo Niepołomice wynosi $2817776 \mathrm{~m}^{3}$, przeciętna zasobność na 1 ha jest równa $277 \mathrm{~m}^{3} /$ ha, a przyrost bieżący roczny osiąga przeciętnie $59825 \mathrm{~m}^{3}$, co w przeliczeniu na jednostkę powierzchni daje $5,87 \mathrm{~m}^{3} /$ ha na rok. Teren Puszczy Niepołomickiej jest zróżnicowany siedliskowo. Południowa część zdominowana jest przez bory i bory mieszane, natomiast północna przez grądy, łęgi i olsy (FERCHMIN 1976; Bednarz 1981; Ćwikowa 1981; Gruszczyk 1981; MyczKowski 1981). Według opracowanej przez Biuro Urządzania Lasu i Geodezji Leśnej Prognozy oddziaływania na lata 2012-2021, siedliska mające charakter naturalny lub zbliżony do naturalnego stanowią $83,8 \%$ powierzchni, pozostałe to siedliska przekształcone, stanowiące $16,2 \%$ (Prognoza 2012).

Na terenie Puszczy Niepołomickiej jest prowadzona przebudowa drzewostanów, głównie sosnowych, rębnych i przeszłorębnych na mieszane. Ponad połowa (54\%) drewna jest pozyskiwana poprzez cięcia rębne. Pozostałe $46 \%$ pochodzi z zabiegów pielęgnacyjnych, jak czyszczenia, trzebieże wczesne i późne oraz użytki przygodne. W strukturze gatunkowej najważniejsze znaczenie ma sosna zwyczajna Pinus sylvestris, zajmująca $62 \%$ powierzchni leśnej. Ważnymi gatunkami są także dęby: szypułkowy Quercus robur i bezszypułkowy Q. petraea, które panują na 19,2\% powierzchni. Kolejnym jest olsza czarna Alnus glutinosa, która zajmuje 11,2\% powierzchni. Z pozostałych 13 gatunków żaden nie przekracza $5 \%$ udziału powierzchniowego. Gatunki pochodzenia obcego mają znaczenie marginalne i neofityzacja nie stanowi problemu hodowlanego. Biorąc pod uwagę zgodność obecnego składu gatunkowego ze składem docelowym, można stwierdzić, że około 35\% drzewostanów ma skład zgodny z pożądanym, natomiast $60 \%$ jest częściowo zgodne (PUL 2011). Przedstawiony powyżej problem niepełnej zgodności drzewostanu z siedliskiem będzie w przyszłości rzutował na prowadzoną gospodarkę leśną, której celem stanie się przebudowa drzewostanów na zgodne z siedliskowym typem lasu. To z kolei wpłynie na stosowane cięcia i zabiegi pielęgnacyjne oraz możliwości i sposoby pozostawiania martwego drewna w drzewostanie.

Struktura gatunkowa drzewostanów przekłada się na udział gatunków drewna w pozyskaniu. Surowiec iglasty stanowi 60\%, natomiast drewno liściaste - 40\%, na co wpływ ma także prowadzona przebudowa monokultur sosnowych. Biorąc pod uwagę strukturę gatunkową drzewostanów w starszych klasach wieku, drzewostany ponad stuletnie tworzą sosna zwyczajna i dęby. Drzewostany w wieku 101-120 lat zajmują 17\% powierzchni Puszczy Niepołomickiej i 62\% ich składu gatunkowego stanowi sosna zwyczajna. Z kolei drzewostany starsze niż 140 lat zajmują 22\% powierzchni i tworzą je głównie dęby. Znaczna powierzchnia drzewostanów w starszych klasach wieku wynika z przyjętego, wysokiego wieku rębności, który dla dębów wynosi 180 lat, dla jesionu wyniosłego Fraxinus excelsior oraz buka zwyczajnego Fagus sylvatica - 120 lat, dla sosny - 110 lat, grabu - 100 lat, a dla brzóz i olchy czarnej - 80 lat. Średni wiek drzewostanów w Nadleśnictwie Niepołomice wynosi ok. 65 lat (PUL 2011). 
Puszcza Niepołomicka w całości jest Obszarem Specjalnej Ochrony Ptaków (PLB120002). Ponadto dwa fragmenty lasu zostały uznane za specjalne obszary ochrony siedlisk: „Koło Grobli” (PLH120008; 597,85 ha) i „Lipówka” (PLH120010; 25,73 ha). Wszystkie zostały ustanowione Rozporządzeniem Ministra Ochrony Środowiska w 2004 r. Wcześniej, w latach 90. XX w., uzyskała status Leśnego Kompleksu Promocyjnego.

\section{METODYKA BADAŃ}

W celu wyznaczenia powierzchni badawczych wytypowano 183 oddziały i w geometrycznym środku każdego oddziału wyznaczono punkt, który stał się centralnym punktem powierzchni. Wybrane oddziały tworzyły mniej więcej regularną szachownicę w obrębie całego kompleksu leśnego. W każdym z wytypowanych oddziałów od centralnego punktu wyznaczono powierzchnię badawczą o wielkości $200 \mathrm{~m} \times 20 \mathrm{~m}$ ( 0,4 ha). Powierzchnie zostały trwale zaznaczone w terenie, aby w następnych latach była możliwość prowadzenia na nich obserwacji. Łącznie, wszystkie wyznaczone w terenie powierzchnie objęły 74,8 ha lasu. Na każdej spośród 183 powierzchni w latach 2015-2016 zmierzono leżące na powierzchni gleby kłody o grubości ponad $10 \mathrm{~cm}$ na grubszym końcu oraz stojące martwe pnie o grubości powyżej $10 \mathrm{~cm}$ na wysokości $1,3 \mathrm{~m}$. Każdy fragment martwego drewna został przyporządkowany do gatunku i jednego z pięciu przyjętych stopni rozkładu oraz zmierzono jego średnicę, długość lub wysokość. Pomiary te były wykorzystane do obliczenia miąższości każdego fragmentu przy pomocy wzoru na stożek ścięty. Wyznaczone powierzchnie badawcze były zlokalizowane w 183 oddziałach oraz 365 wydzieleniach.

Odtworzono historię pozyskania drewna w latach 2010-2015, biorąc pod uwagę wyłącznie surowiec, który został wycięty w wyniku prowadzonej gospodarki leśnej, pomijając naturalne wypady. Dane pochodziły z Systemu Informatycznego Lasów Państwowych (SILP), z formularzy LPIO 1 „Informacja o wykonaniu cięć” oraz LPIO 4 ,Kwartalny meldunek o postępie prac w hodowli i ochronie lasu”. Uwzględniony okres sześciu lat objął czas obowiązywania dwóch Planów Urządzenia Lasu (PUL 2002, 2011): pierwszy na lata 2002-2011 (w badaniach uwzględniono lata 2010-2011), drugi na lata 2012-2021 (uwzględniono lata 2012-2015). Na podstawie uzyskanych danych dla badanych oddziałów i wydzieleni, w których znajdowały się powierzchnie badawcze, obliczono sumaryczną wielkość pozyskania drewna w ciągu sześciu lat, w rozbiciu na grupy czynności gospodarczych oraz gatunki. Jeżeli powierzchnia badawcza była usytuowana w kilku wydzieleniach, to intensywność pozyskania obliczano jako średnią ważoną udziałem powierzchniowym poszczególnych wydzieleń w granicach powierzchni.

Każdą powierzchnię badawczą przyporządkowano do jednej z trzech grup siedliskowych typów lasu: 1) bory i bory mieszane na siedliskach świeżych i wilgotnych, 2) lasy i lasy mieszane na siedliskach świeżych i wilgotnych oraz 3) olsy i olsy jesionowe. W dalszej części tekstu dla tych trzech grup używane są nazwy: bory, grądy i olsy. Jeśli powierzchnia przecinała wydzielenia leśne z różnymi typami siedliskowymi lasu, zaliczono ją do typu dominującego pod względem zajmowanego obszaru.

Analizie poddano związek ilości drewna pozyskanego w ramach wykonywania poszczególnych rodzajów cięć (cięcia przedrębne przygodne, cięcia przedrębne planowane i cięcia rębne) w latach 2010-2015 a ilością martwego drewna stwierdzonego w latach 2015-2016, uwzględniając miąższość leżących kłód i miąższość posuszu stojącego oraz ich sumę. Analizę przeprowadzono dla wszystkich powierzchni badawczych łącznie oraz oddzielenie dla każdego z trzech typów lasu: borów, grądów i olsów. $\mathrm{W}$ analizie uwzględniono jedynie powierzchnie, na których pozyskiwano drewno. Cięcia przygodne wykonano na 142 powierzchniach, planowane cięcia trzebieżowe na 96 powierzchniach, a cięcia rębne na 36 powierzchniach.. Zależności między zmiennymi badano przy użyciu korelacji rang Spearmana, uznając istotność statystyczną związku przy $p<0,05$. Analizy prowadzono w programie STATISTICA 9.0 (StatSoft Inc., USA). 


\section{WYNIKI}

\section{Wielkość pozyskania drewna według zabiegów gospodarczych i gatunków}

Całkowita miąższość drewna pozyskanego w latach 2010-2015, w analizowanych 365 wydzieleniach o łącznej powierzchni 2636 ha, wyniosła $53967 \mathrm{~m}^{3}$. Największą ilość drewna, 43\% całości, pozyskano w cięciach rębnych $\left(23299 \mathrm{~m}^{3}\right)$, z czego ponad połowa przypadała na rębnię gniazdową zupełną (IIIA). Tak duża ilość pozyskanego drewna wynikała $\mathrm{z}$ wysokiej intensywności cięć $\mathrm{w}$ poszczególnych wydzieleniach, przy ich znacznie mniejszym zasięgu powierzchniowym w porównaniu z innymi rodzajami cięć. W cięciach trzebieżowych pozyskano $18933 \mathrm{~m}^{3}$ drewna, co stanowiło 35\% całości. W tej kategorii cięć ponad dwie trzecie drewna pochodziło z trzebieży późnej pozytywnej. W cięciach przygodnych użytkowano w sumie $11734 \mathrm{~m}^{3}$, co stanowiło $22 \%$ drewna pozyskanego w badanych

Tabela 1. Wielkość pozyskania drewna w badanych 365 wydzieleniach Puszczy Niepołomickiej w latach 2010-2015 z podziałem na poszczególne rodzaje zabiegów

Table 1. Volume of timber harvested in 365 studied forest compartments in the Niepołomice Forest in 2010-2015, by forest management practice

\begin{tabular}{lccccccc}
\hline \hline $\begin{array}{l}\text { Rodzaj zabiegów } \\
\text { (Type of practice) }\end{array}$ & 2010 & 2011 & 2012 & 2013 & 2014 & 2015 & $\begin{array}{c}\text { Razem } \\
(\text { Total) } \\
{\left[\mathrm{m}^{3}\right]}\end{array}$ \\
\hline CP-P & 3,3 & 3,9 & 3,9 & 8,9 & 2,6 & 0 & 19,3 \\
IA & 0 & 175,3 & 0 & 0 & 0 & 0 & 175,3 \\
IB & 0 & 200,0 & 1686,3 & 1502,8 & 0 & 299,1 & 3688,3 \\
IIBU & 0 & 0 & 557,4 & 0 & 0 & 0 & 557,4 \\
IIIA & 0 & 335,6 & 478,8 & 3502,2 & 3044,1 & 6010,5 & 13371,1 \\
IIIBU & 0 & 0 & 0 & 0 & 697,0 & 544,8 & 1241,8 \\
IIIB & 0 & 0 & 0 & 0 & 972,2 & 1681,7 & 2653,9 \\
IVD & 0 & 0 & 0 & 0 & 1153,3 & 438,6 & 1591,9 \\
PR & 118,3 & 110,8 & 434,1 & 376,7 & 1061,3 & 446,5 & 2547,8 \\
PTP & 1579,8 & 1652,9 & 1199,1 & 1108,4 & 1474,9 & 1437,2 & 8452,3 \\
PTW & 161,1 & 174,8 & 321,0 & 20,5 & 56,6 & 0,4 & 734,4 \\
TPN & 731,5 & 297,4 & 1074,7 & 228,6 & 631,0 & 575,8 & 3538,9 \\
TPP & 1340,3 & 469,0 & 1847,8 & 3019,0 & 2574,3 & 3967,1 & 13217,5 \\
TWN & 0 & 100,0 & 0 & 0 & 0 & 0 & 100,0 \\
TWP & 211,9 & 297,1 & 450,8 & 330,8 & 350,3 & 435,8 & 2076,7 \\
\hline
\end{tabular}

Akronimy/skróty: CP-P - czyszczenia późne z pozyskaniem drewna, IA - rębnia zupełna wielkopowierzchniowa, IB - rębnia zupełna pasowa, IIBU - cięcia uprzątające rębni częściowej pasowej, IIIA - rębnia gniazdowa zupełna, IIIBU - cięcia uprzątające rębni gniazdowej częściowej, IIIB - rębnia gniazdowa częściowa, IVD - rębnia stopniowa udoskonalona, PR - cięcia przygodne rębne, PTP - cięcia przygodne trzebieży późnej, PTW - cięcia przygodne trzebieży wczesnej, TPN - trzebież późna negatywna, TPP - trzebież późna pozytywna, TWN - trzebież wczesna negatywna, TWP - trzebież wczesna pozytywna.

Acronyms/abbreviations: CP-P - late cleaning, IA - large-area clearcutting, IB - strip clearcutting, IIBU - removal (final) cut of shelterwood strip cutting, IIIA - group clearcutting system, IIIBU - removal (final) cut of shelterwood group cutting system, IIIB - shelterwood group cutting system, IVD - stepwise cutting, PR - incidental final felling, PTP - incidental felling of late thinning, PTW - incidental felling of early thinning, TPN - negative late thinning, TPP - positive late thinning, TWN - negative early thinning, TWP - positive early thinning. 
wydzieleniach. W tej kategorii cięć prawie trzy czwarte drewna pozyskano w cieciach przygodnych trzebieży późnej (Tab. 1).

Wielkość pozyskania drewna znacznie różniła się między latami. Bardzo małe pozyskanie w 2010 r. i jeszcze niższe w 2011 r. było związane z kończącym się okresem realizacji planu urządzania lasu na lata 2002-2011. Począwszy od 2012 r. realizowany był nowy plan i pozyskanie znacząco wzrosło.

Cięcia przygodne w wydzieleniach, w których zlokalizowano powierzchnie badawcze, wykonano w sumie 394 razy, co stanowiło 59,4\% wszystkich zbiegów. Najczęściej wykonywanym zabiegiem gospodarczym były cięcia przygodne trzebieży późnej, które stanowiły ponad połowę wszystkich wykonanych zabiegów gospodarczych. Frekwencja cięć przygodnych rębnych uplasowała je na drugim miejscu, a na trzecim znalazły się cięcia przygodne trzebieży wczesnej (Tab. 2).

Trzebieże wczesne w badanych wydzieleniach miały niską frekwencję i stanowiły niespełna 5,3\% wszystkich zabiegów. Częściej wykonywano trzebieże późne, które stanowiły 13,4\% wszystkich zabiegów. Najwyższą frekwencję wśród cięć rębnych miała rębnia gniazdowa zupełna (Tab. 2).

W strukturze gatunkowej pozyskania drewna dominowała sosna, stanowiąca $57,8 \%$. Duże znaczenie miały także: dęby, olcha, brzoza i inne gatunki liściaste. Struktura gatunkowa użytkowanego drewna wynika z prezentowanego powyżej składu gatunkowego

Tabela 2. Frekwencja zabiegów gospodarczych w 365 wydzieleniach Nadleśnictwa Niepołomice w latach 2010-2015 z podziałem na rodzaje zabiegów

Table 2. Frequency of forest management practices in 365 forest compartments of the Niepołomice Forest in 2010-2015

\begin{tabular}{|c|c|c|c|c|c|c|c|}
\hline \multirow[t]{2}{*}{$\begin{array}{l}\text { Rodzaj zabiegów } \\
\text { (Type of practice) }\end{array}$} & \multicolumn{6}{|c|}{$\begin{array}{c}\text { Liczba wydzieleń objętych wykonaniem czynności gospodarczych } \\
\text { (Number of forest compartments covered by a given forest } \\
\text { management practice) }\end{array}$} & \multirow{2}{*}{$\begin{array}{l}\text { Razem ilość zabiegów } \\
\text { (Total number of } \\
\text { treatments) }\end{array}$} \\
\hline & 2010 & 2011 & 2012 & 2013 & 2014 & 2015 & \\
\hline CP-P & 1 & 1 & 2 & 1 & 1 & 0 & 6 \\
\hline IA & 0 & 1 & 0 & 0 & 0 & 0 & 1 \\
\hline IB & 0 & 1 & 3 & 2 & 0 & 1 & 7 \\
\hline IIBU & 0 & 0 & 1 & 0 & 0 & 0 & 1 \\
\hline IIIA & 0 & 1 & 2 & 9 & 7 & 6 & 25 \\
\hline IIIBU & 0 & 0 & 0 & 0 & 1 & 1 & 2 \\
\hline IIIB & 0 & 0 & 0 & 0 & 2 & 4 & 6 \\
\hline IVD & 0 & 0 & 0 & 0 & 1 & 2 & 3 \\
\hline PR & 5 & 2 & 13 & 17 & 23 & 34 & 94 \\
\hline PTP & 50 & 51 & 59 & 59 & 63 & 72 & 354 \\
\hline PTW & 10 & 8 & 7 & 3 & 11 & 1 & 40 \\
\hline TPN & 6 & 3 & 7 & 2 & 4 & 2 & 24 \\
\hline TPP & 10 & 5 & 11 & 16 & 10 & 13 & 65 \\
\hline TWN & 0 & 2 & 0 & 0 & 0 & 0 & 2 \\
\hline TWP & 6 & 5 & 7 & 4 & 4 & 7 & 33 \\
\hline Razem (Total) & 88 & 80 & 112 & 113 & 127 & 143 & 663 \\
\hline
\end{tabular}

Akronimy/skróty jak w tabeli 1. Acronyms/abbreviations as in Table 1. 

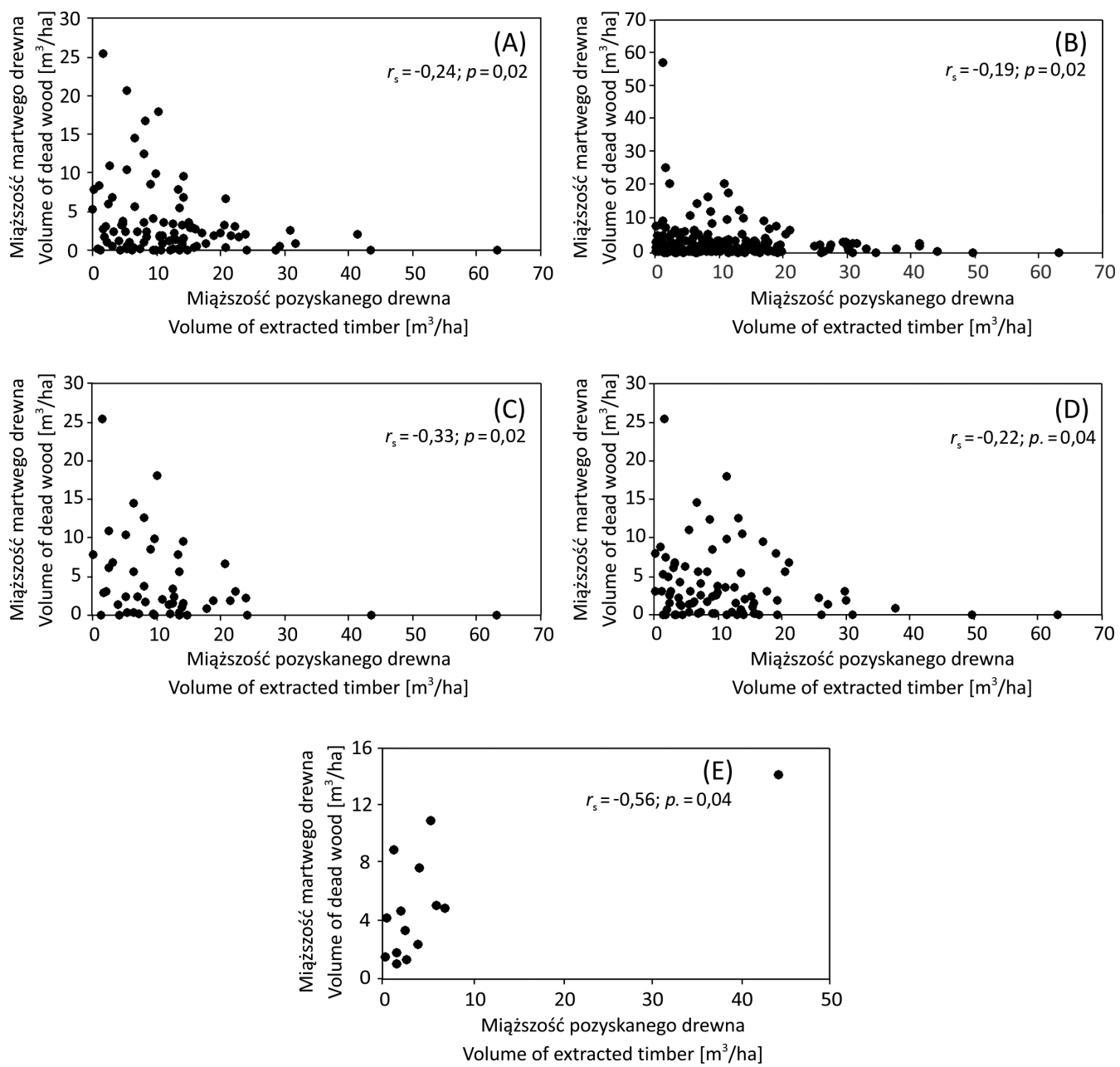

Ryc. 1. Zależność między: (A) - miąższością drewna pozyskanego w planowanych trzebieżach a miąższością stojącego posuszu we wszystkich typach lasu; (B) - miąższością drewna pozyskanego w cięciach przygodnych i planowanych trzebieżach a miąższością stojącego posuszu we wszystkich typach lasu; (C) - miąższością drewna pozyskanego w planowanych trzebieżach a miąższością stojącego posuszu w grądach; (D) - miąższością drewna pozyskanego w cięciach przygodnych i planowanych trzebieżach a miąższością stojącego posuszu w grądach; E - miąższością drewna pozyskanego w cięciach przygodnych a miąższością kłód w olsach

Fig. 1. Relationships between (A) the volume of timber harvested during thinning and the volume of snags in all three forest types; (B) the volume of timber harvested during incidental felling and thinning and the volume of snags in all three forest types; (C) the volume of timber harvested during thinning and the volume of snags in oak-hornbeam forest; (D) the volume of timber harvested during incidental felling and thinning and the volume of snags in oak-hornbeam forest; (E) the volume of timber harvested during incidental felling and the volume of logs in black alder swamp forest

drzewostanów Nadleśnictwa Niepołomice i realizowanego procesu przebudowy, mającego na celu zmniejszenie udziału sosny wprowadzonej w przeszłości. Udział drewna gatunków liściastych, a szczególnie dębu i olszy jest proporcjonalny do ich udziału powierzchniowego. 


\section{Obecność martwego drewna w powiązaniu z wykonywanymi zabiegami gospodarczymi}

Przy uwzględnieniu wszystkich powierzchni badawczych stwierdzono, że tylko miąższość martwych stojących pni była negatywnie związana z ilością drewna pozyskanego w planowanych trzebieżach (Ryc. 1A) oraz z całkowitą ilością drewna pozyskanego podczas wszystkich cięć przedrębnych (planowanych trzebieży i cięć przygodnych; Ryc. 1B). Zarówno miąższość kłód, jak i też całkowita miąższość martwego drewna nie była istotnie skorelowana z intensywnością cięć przygodnych i trzebieżowych, traktowanych osobno jak i łącznie. Podobnie nie wykazano żadnego związku między intensywnością cięć rębnych a ilością martwego drewna. Wartość współczynnika korelacji $r_{S} \mathrm{w}$ tych pozostałych przypadkach mieściła się w przedziale od $-0,10$ do 0,09 .

W borach nie wykazano ani jednego przypadku istotnego związku ilości martwego drewna z nasileniem cięć przygodnych i trzebieżowych. Wartość współczynnika korelacji $r_{S}$ wahała się od $-0,20$ (w przypadku cięć przygodnych i miąższości kłód) do 0,22 (w przypadku cięć trzebieżowych i miąższości kłód).

W grąach stwierdzono dwa istotne związki. Miąższość posuszu stojącego była negatywnie skorelowana z ilością drewna pozyskanego w ramach trzebieży (Ryc. 1C) i z ilością drewna pozyskanego w trakcie wszystkich cięć przedrębnych (Ryc. 1D). W pozostałych przypadkach wartości współczynnika korelacji $r_{S}$ były bliskie zera.

W olsach stwierdzono jeden istotny związek natężenia cięć z ilością martwego drewna. Miąższość kłód była pozytywnie skorelowana z ilością drewna pozyskanego w ramach cięć przygodnych (Ryc. 1E). We wszystkich pozostałych przypadkach współczynnik korelacji $r_{S}$ również był dodatni i trzykrotnie przekroczył wartość 0,2 .

\section{DYSKUSJA}

Ilość i różnorodność martwego drewna należą do najważniejszych czynników determinujących bogactwo gatunkowe biocenoz leśnych (GUTOWSKI i in. 2004; BRODZIAK \& HILSZCZAŃSKI 2012; STOKLAND i in. 2012)). Ilość martwego drewna w lasach gospodarczych w niewielkim stopniu zależy od naturalnych procesów rządzących obumieraniem drzew i rozkładem ich szczątków (KAPUSTA i in. 2020). Pierwszoplanowe stają się warunki prowadzenia gospodarki leśnej i decyzje podejmowane w trakcie wykonywania wszelkiego rodzaju cięć, które mają na uwadze efekt ekonomiczny. Zwiększenie ilości martwego drewna w gospodarce leśnej często skutkuje z jednej strony wzrostem utraconych przychodów, a z drugiej - zwiększeniem kosztów prowadzenia tej gospodarki (DAwIDZIUK 2006). Dlatego dążenia do zapewnienia odpowiednich warunków bytowania gatunkom saproksylicznym napotykają w lasach gospodarczych na trudności (SŁAWSKI 2007).

Dla zapewnienia obecności martwego drewna bardzo ważne jest pozyskanie drewna w ramach cięć przygodnych, czyli zabiegów, które nie mają charakteru planowego. Głównym celem tych cięć jest utrzymanie właściwego stanu sanitarnego lasu. Z tego względu noszą one także nazwę cięć sanitarnych. W trakcie tych cięć usuwane są z lasu drzewa wywrócone i złamane, a także drzewa dziuplaste oraz opanowane przez owady i grzyby, 
co sprowadza się do eliminacji zarówno posuszu stojącego jak i leżącego (BuJoczeK i in. 2019). W przypadku Puszczy Niepołomickiej, kompleksu leśnego otoczonego licznymi miejscowościami, dodatkową rolą cięć przygodnych jest zaspokajanie bieżących potrzeb lokalnego rynku drzewnego na drewno opałowe i inne sortymenty drewna gorszej jakości. Cięcia te dostarczyły nieco ponad jedną piątą drewna pozyskanego w ciągu analizowanych sześciu lat.

Cięcia przygodne prowadzone są zarówno w tych fragmentach lasu, gdzie obumarły pojedyncze drzewa, jak i tam, gdzie zamieranie miało charakter masowy, a ich nasilenie zależy przede wszystkim od intensywności wydzielania się drzew. Ilość drewna pozyskanego cięciami przygodnymi nie jest zwykle duża, jednak objęta jest nimi znaczna część lasu i często są prowadzone wielokrotnie w tych samych miejscach. W Puszczy Niepołomickiej wykonanie tego zabiegu w ciągu sześciu lat zanotowano na 142 spośród 183 powierzchni badawczych, przy czym w co trzecim wydzieleniu, spośród tych przez które przechodziły powierzchnie, były one wykonane co najmniej dwukrotnie. W ramach gospodarki leśnej ukierunkowanej na utrzymanie jak najlepszego stanu sanitarnego drzewostanu, rezultatem cięć przygodnych jest wszędzie jednakowa i bardzo mała ilość martwego drewna, ponieważ jego sprzedaż, mimo niskiej ceny, stanowi znaczącą pozycję w dochodach gospodarstwa leśnego (Gołos 2012). Natomiast na obszarach pełniących także znaczącą rolę w ochronie przyrody, jak np. na obszarach Natura 2000, niska cena rynkowa części obumierających i martwych drzew, jeśli nie stanowią zagrożenia dla drzewostanu, powinna skłaniać do pozostawienia ich w lesie (CZEREPKo 2008; REFEROWSKA-CHODAK 2014).

Podejmując niniejsze badania oczekiwano, że w trakcie cięć przygodnych, prowadzonych w ostatnich latach w Puszczy Niepołomickiej, część martwych i obumierających drzew zostaje pozostawionych na miejscu. Przy czym spodziewano się, że im więcej było takich drzew w drzewostanie, tym więcej pozostawało ich po wykonaniu zabiegu. Na tej podstawie sformułowano hipotezę o pozytywnym związku między intensywnością pozyskiwania drewna w ramach cięć przygodnych a ilością martwego drewna obecnego na powierzchniach badawczych. Hipoteza ta została pozytywnie zweryfikowana tylko w odniesieniu do miąższości kłód w olsach. W borach i grądach korelacje nie były istotne statystycznie.

Stwierdzona wyjątkowość olsów jest związana z dwoma czynnikami mającymi wpływ na prowadzenie zabiegów sanitarnych: masowym zamieraniem jesionu i utrudnioną dostępnością terenu. Ograniczona dostępność spowodowana jest większą wilgotnością podłoża i obecnością sporej ilości rowów odwadniających, które utrudniają transport pozyskanego drewna (KAPUSTA i in. 2020). Wydaje się, że te dwa czynniki odgrywają obecnie najważniejszą rolę dla zwiększenia ilości martwego drewna w Puszczy Niepołomickiej.

W planowanych cięciach trzebieżowych, prowadzonych w ciągu sześciu lat w Puszczy Niepołomickiej, pozyskano o $60 \%$ drewna więcej niż w cięciach przygodnych. Miały one zatem bardzo duże znaczenie dla formowania zasobów martwego drewna, choć nie były tak rozpowszechnione jak cięcia przygodne. Wykonano je na 96 spośród 183 powierzchni badawczych. Trzebieże prowadzone są przede wszystkim w celu poprawienia warunków wzrostu i jakości drzew pozostałych po wykonaniu zabiegu oraz regulacji składu gatunkowego drzewostanu. W trzebieżach wczesnych usuwane są drzewa o niewielkich rozmiarach, ponieważ prowadzone są w drzewostanach młodych, zazwyczaj w II klasie wieku 
(21-40 lat). Zadaniem trzebieży późnych, wykonywanych w starszych drzewostanach, jest kształtowanie jakości pni drzew z uwzględnieniem pożądanych sortymentów drzewnych oraz zwiększenie produkcyjności siedliska przez intensyfikację procesów glebowych, wywołanych większym udostępnieniem ciepła, światła i wilgoci (ZASADY 2012). Z punktu widzenia zwiększenia zasobów martwego drewna szczególnie ważne jest nasilenie trzebieży późnych, ponieważ w ich trakcie usuwane są z lasu pnie o średnich i dużych rozmiarach, w których organizmy saproksyliczne znajdują korzystne warunki do życia.

Podobnie jak w przypadku cięć przygodnych spodziewano się, że w związku z wyznaczeniem obszarów Natura 2000 na terenie Puszczy Niepołomickiej, cięcia trzebieżowe będą miały korzystny wpływ na zwiększanie zasobów martwego drewna. W trakcie tych cięć dochodzi do wycięcia drzew o niewielkich rozmiarach oraz drzew wadliwych o zdeformowanych pniach. Ze względu na niewielkie rozmiary i obniżoną jakość osiagają one stosunkowo małą wartość na rynku drzewnym. Usuwane są też drzewa należące do gatunków, których drewno osiąga niższe ceny. Oczekiwano, że z powodu mniejszej wartości drzew usuwanych w trakcie trzebieży nasilenie tego zabiegu jest pozytywnie skorelowane z ilością pozostawionego martwego drewna. W żadnym z trzech typów lasu (bory, grądy, olsy) nie stwierdzono istotnego, pozytywnego związku między nasileniem trzebieży a ilością martwego drewna w postaci posuszu stojącego i kłód. W jednym przypadku uzyskano dodatni współczynnik korelacji $r_{S}$ o wartości ponad 0,2 (między nasileniem trzebieży a miąższością kłód w borach), jednak nie różnił się on istotnie od zera $(p=0,23)$. Stwierdzono natomiast dwa istotne związki negatywne. Taki kierunek miały w grądach zmiany miąższości stojących martwych pni w gradiencie natężenia trzebieży i natężenia wszystkich cięć przedrębnych (razem trzebieże i cięcia sanitarne). Wynik ten oznacza, że w trakcie wykonywania trzebieży w grądach następuje wycinanie posuszu stojącego i usuwanie go z lasu. Wycięte martwe pnie nie zasilają zasobów leżaniny, ponieważ ta nie zmienia się w gradiencie intensywności trzebieży $\left(r_{S}=0,04\right)$. Uzyskany wynik ujawnia, że w grądach po wykonaniu trzebieży nie tylko nie dochodziło do zwiększenia zasobów martwego drewna, ale było ono z lasu usuwane.

Wynik ten jest o tyle zaskakujący, że w związku z utworzeniem Obszaru Specjalnej Ochrony Ptaków w ramach Natura 2000, wielkość zasobów martwego drewna w grądach powinna być czterokrotnie większa niż w borach (ZARZĄDZENIE 2014). Ponadto, stojące martwe pnie należą do tych elementów lasu, które są chętnie wykorzystywane przez dziuplaki do zakładania gniazd (LõHMUS 2016; BARRY i in. 2018). Puszcza Niepołomicka należy do najważniejszych ostoi dzięcioła średniego Leiopicus medius w Polsce (WILK i in. 2013), a optymalne warunki dla żerowania i gniazdowania ptak ten znajduje w grądach, przy czym często wykuwa dziuple w martwych stojących pniach (HEBDA i in. 2016; KosińsKI $\mathrm{i}$ in. 2018).

Najtańszym sposobem zwiększenia ilości martwych pni w lesie gospodarczym jest pozostawienie w nim naturalnie zamierających drzew (RANIUS i in. 2005). To rozwiązanie powinno być jak najbardziej zalecane w warunkach gospodarki leśnej na terenach chronionych, jakimi są obszary Natura 2000. Dotyczy to zwłaszcza pozostawiania części martwych drzew w trakcie wykonywania cięć przedrębnych, kiedy pozyskiwany jest surowiec drzewny o mniejszej wartości z ekonomicznego punktu widzenia. Do najbardziej 
efektywnych, pod względem zmniejszania strat ekonomicznych przy osiąganiu możliwie największych korzyści biocenotycznych, należy ograniczanie cięć przygodnych w trudnodostępnych miejscach intensywnego wydzielania się posuszu. W przypadku Puszczy Niepołomickiej takie podejście zdaje się być w pewnym stopniu realizowane na trudnodostępnych siedliskach wilgotnych i podmokłych, gdzie od lat zachodzi proces zamierania jesionu (KAPUSTA i in. 2020). Ma to racjonalne uzasadnienie ekonomiczne, ponieważ usuwanie drzew poklęskowych generuje znacznie wyższe jednostkowe koszty pozyskania i zrywki (Progar i in. 2007; Szabla 2011; PiszCZEK 2013). Celowym zatem jest uznanie za konieczne ograniczenie pozyskania drewna w cięciach przygodnych oraz trzebieżach późnych, zwłaszcza na terenach słabo dostępnych o utrudnionej gospodarce leśnej. Jest to najtańszy sposób (minimalizujący utracone przychody i ograniczający koszty wykonywania zabiegów) na szybki przyrost ilości martwych drzew na terenach, gdzie z perspektywy potrzeb ochrony przyrody tego elementu lasu powinno istotnie przybyć w możliwie krótkim czasie.

Podziękowania. Badania były finansowane z środków Państwowego Gospodarstwa Leśnego Lasy Państwowe w ramach grantu pt. Kształtowanie się zasobów martwego drewna $w$ siedliskach przyrodniczych $w$ warunkach prowadzenia zrównoważonej gospodarki leśnej (Nr OR.271.3.9.215) oraz środków statutowych Instytutu Botaniki im. W. Szafera Polskiej Akademii Nauk. Autorzy dziękują również Nadleśnictwu Niepołomice za umożliwienie prowadzenia badań na terenie Puszczy Niepołomickiej oraz wszystkim osobom, które brały udział w pracach terenowych.

\section{LITERATURA}

Barry A. M., Hagar J. C. \& Rivers J. W. 2018. Use of created snags by cavity-nesting birds across 25 years. - Journal of Wildlife Management 82: 1376-1384.

Bednarz Z. 1981. Bory Puszczy Niepołomickiej. - Studia Ośrodka Dokumentacji Fizjograficznej 9: 89-115.

BRoDZIAK Ł. \& HiLSZCZAŃSKI J. 2012. Ochrona lasu i bioróżnorodności a produkcja drewna. - W: Zimowa Szkoła Leśna przy Instytucie Badawczym Leśnictwa, IV Sesja „Przyrodnicze i gospodarcze aspekty produkcji oraz wykorzystania drewna - stan obecny i prognoza”, 20-22 marca 2012 r., s. 76-84. Instytut Badawczy Leśnictwa, Sękocin Stary.

Bujoczek L., Szewczyk A., Zygmunt R., Bujoczek M., Zięba S., Banaś J. \& Kożuch A. 2019. Posusz, złomy, wywroty jako elementy planowania i pozyskania w Nadleśnictwie Krasnystaw w latach 2006-2015. - Acta Scientiarum Polonorum Silvarum Colendarum Ratio et Industria Lignaria 18(2): 83-91.

CZERePKo J. (red.). 2008. Stan różnorodności biologicznej lasów w Polsce na podstawie powierzchni obserwacyjnych monitoringu. Synteza wyników uzyskanych w ramach realizacji projektu BioSoil Forest Biodiversity. s. 135. Instytut Badawczy Leśnictwa, Sękocin Stary.

ĆwıKowa A. 1981. Lasy łęgowe Puszczy Niepołomickiej. - Studia Ośrodka Dokumentacji Fizjograficznej 9: $131-149$.

DAwidziuk J. 2006. Perspektywy obecnego modelu leśnictwa państwowego w Polsce - debata środowiskowa. - Przegląd Leśniczy 11: 22-29.

Ferchmin M. 1976. Oles Carici elongatae-Alnetum oraz zbiorowiska ze związku Salicion i Alno-Padion w północnej części Puszczy Niepołomickiej. - Studia Naturae, Seria A 13: 107-142. 
GoŁos P. 2012. Koszty świadczenia pozaprodukcyjnych funkcji gospodarki leśnej na przykładzie Regionalnej Dyrekcji Lasów Państwowych w Katowicach. - Leśne Prace Badawcze 73: 209-220.

GruszczYK A. 1981. Siedliskowe typy lasu Puszczy Niepołomickiej. - Studia Ośrodka Dokumentacji Fizjograficznej 9: 205-216.

Gutowski J. M., Bobiec A., Pawlaczyk P. \& Zub K. 2004. Drugie życie drzewa. s. 245. WWF Polska, Warszawa - Hajnówka.

Hebda G., Wesolowski T. \& Rowiński P. 2016. Nest sites of Middle Spotted Woodpeckers Leiopicus medius in a primeval forest. - Ardea 104(2): 119-128.

KAPUŚCIŃSKI R. 2007. Natura 2000 konsekwencje dla leśników i drzewiarzy. - Przemysł Drzewny 6: 13-15.

Kapusta P., Kurek P., Piechnik Ł., Szarek-Łukaszewska G., Zielonka T., Żywiec M. \& Holeksa J. 2020. Natural and human-related determinants of dead wood quantity and quality in a managed European lowland temperate forest. - Forest Ecology and Management 459: 117845.

Kosiński Z., Pluta M., Ulanowska A., WalcZaK Ł., Winiecki A. \& ZarĘBSKI M. 2018. Do increases in the availability of standing dead trees affect the abundance, nest-site use, and niche partitioning of great spotted and middle spotted woodpeckers in riverine forests? - Biodiversity Conservation 27: 123-145.

LõHMUS A. 2016. Habitat indicators for cavity-nesters: The polypore Phellinus pini in pine forests. - Ecological Indicators 66: 275-280.

Mróz W. (red.). 2012. Monitoring siedlisk przyrodniczych. Przewodnik metodyczny. Część III. s. 338. Główny Inspektorat Ochrony Środowiska, Warszawa.

MyczKowski S. 1981. Lasy grądowe Puszczy Niepołomickiej. - Studia Ośrodka Dokumentacji Fizjograficznej 9: 117-130.

PISZCZEK M. 2013. Wpływ gradacji kornika drukarza Ips typographus (L.) na realizację zadań gospodarczych i sytuację finansową wybranych nadleśnictw w Beskidzie Śląskim i Żywieckim (RDLP Katowice). - Zeszyty Naukowe Uniwersytetu Rolniczego im. Hugona Kołłątaja w Krakowie 507, Rozprawy 384: 1-110.

Progar R. A., Eglitis A. \& Lundquist J. E. 2007. Some ecological, economic, and social consequences of bark beetle infestations. - W: J. L. HAYES \& J. E. LuNDQUist (red.), The western bark beetle research group: a unique collaboration with forest health protection. Proceedings of a Symposium at the 2007 Society of American Foresters Conference, General Technical Report PNW-GTR-784, s. 71-83. United States Department of Agriculture, Forest Service, Pacific Northwest Research Station, Portland, Oregon.

PrognOza 2012. Prognoza oddziaływania na środowisko projektu Planu Urządzenia Lasu Nadleśnictwa Niepołomice. 2012. Mskr. Biuro Urządzania Lasu i Geodezji Leśnej, Kraków.

PUL. 2002. Plan Urządzenia Lasu Nadleśnictwa Niepołomice na okres obowiązywania 01.01.2002 r. $-31.12 .2011 \mathrm{r}$.

PUL. 2011. Nadleśnictwo Niepołomice, Obręb Niepołomice, Plan Urządzenia Lasu na okres gospodarczy od 1 stycznia 2012 r. do 31 grudnia 2021 r. Elaborat. Ogólny opis lasów Nadleśnictwa. s. 372. Biuro Urządzania Lasu i Geodezji Leśnej, Oddział w Krakowie.

Ranius T., Ekvall H., Jonsson M. \& Bostedt G. 2005. Cost-efficiency of measures to increase the amount of coarse woody debris in managed Norway spruce forests. - Forest Ecology and Management 206: $119-133$.

REFEROWSKA-CHODAK E. 2014. Problematyka martwego drewna i drzew dziuplastych w systemach certyfikacji FSC i PEFC. - Studia i Materiały Centrum Edukacji Przyrodniczo-Leśnej w Rogowie 41(4): 98-115.

SŁAWSKI M. 2007. Metoda oceny zróżnicowania struktury lasu jako wskaźnik bioróżnorodności biologicznej. - Studia i Materiały Centrum Edukacji Przyrodniczo-Leśnej w Rogowie 16(2-3): 337-345. 
Stokland J., Sittonen J. \& Jonsson B. G. 2012. Biodiversity in dead wood. s. xiv + 494. Cambridge University Press, Cambridge.

SzABLA K. 2011. Ekonomiczne konsekwencje klęsk żywiołowych w lasach na przykładzie Regionalnej Dyrekcji Lasów Państwowych w Katowicach. - W: „Współczesne problemy ekonomiki leśnictwa”, Międzynarodowa konferencja organizowana pod patronatem Przewodniczacego Polskiego Towarzystwa Leśnego oraz Dyrektora Generalnego Lasów Państwowych, Puszczykowo 7-9 czerwca 2011 r., s. $265-302$.

Ustawa z dnia 28 września 1991 r. o lasach (Dz. U. 1991 nr 101, poz. 444), tekst ujednolicony (Dz. U. z 2020 r. poz. 6).

Wilk T., Bobrek R., Paciora K. \& Springer S. 2013. Wybrane ptaki lęgowe Puszczy Niepołomickiej w latach 2004-2011. - Ornis Polonica 54: 50-67.

ZARZĄDZENIE 2014. Zarządzenie regionalnego dyrektora ochrony środowiska w Krakowie z dnia 8 sierpnia 2014 r. w sprawie ustanowienia planu zadań ochronnych dla obszaru Natura 2000 Puszcza Niepołomicka PLB120002 (Dz. U. Woj. Małopolskiego z 2014 r. poz. 4390).

ZASADY 2012. Zasady Hodowli Lasu. s. 72. Centrum Informacyjne Lasów Państwowych, Warszawa.

Zielony R. \& Kliczkowska A. 2012. Regionalizacja przyrodniczo-leśna Polski 2010. s. 356. Centrum Informacyjne Lasów Państwowych, Warszawa.

\section{SUMMARY}

The aim of the study was determine the impact of forestry practices (incidental felling and thinning) on the amount of deadwood in managed forests protected at Natura 2000 sites. Deadwood was inventoried in 183 sample plots located in 365 forest compartments in the Niepołomice Forest District, and classified as snags or logs. Using data on harvested timber from 2010-2015, total amounts of timber harvested under 14 types of silviculture practice were recorded (Tab. 1). The percentage shares of the volume of logs harvested over the six-year period were calculated for each silviculture practice and each forest compartment. The most frequent silviculture practices were incidental felling during late thinning, incidental cutting, incidental felling during early thinning, and sanitation cutting (Tab. 2). These practices involved selective cutting of dead and dying, weakened, damaged, broken and hollow trees. The amount of deadwood was expected to be positively correlated with the intensity of incidental felling and thinning. A positive correlation was found only for alder forest, where the volume of logs was positively correlated with the intensity of incidental cutting. The opposite relation held for snags in oak-hornbeam forest, where the volume of snags was negatively correlated with the intensity of thinning and the total amount of timber extracted during incidental felling and thinning. We conclude that both deadwood and potential deadwood in the form of dying and suppressed trees are removed from the forest during incidental felling and thinning. That is harmful to saproxylic species. Limitation of these practices at protected sites seems to be the most economical way to improve conditions for these organisms.

Wptynęto: 10.02.2020 r.; przyjęto do druku: 30.03 .2020 r. 